\title{
Functioning of the main elements of the checks and balances system in Ukraine: a comparative analysis under the provisions of different Constitutions
}

\author{
Kh. Zabavska \\ Department of Political Science and International Relations, Lviv Polytechnic National University, Lviv, Ukraine \\ Corresponding author. E-mail: khrystyna.y.zabavska@lpnu.ua
}

Paper received 27.01.20; Accepted for publication 16.02.20.

https://doi.org/10.31174/SEND-HS2020-223VIII37-13

\begin{abstract}
The main elements of the system of checks and balances and their transformation in the course of political practice in Ukraine are considered in the article. Based on the historical method, the article deals with the main historical stages of the checks and balances system development in Ukraine. The article reveals the main differences between the application of the system elements in the conditions of different Constitutions in Ukraine and identifies the main problems concerning their practical implementation. Taking into account the peculiarities of the functioning of the checks and balances system, the transformation of such elements of the checks and balances system as impeachment, legislative initiative, formation of courts and appointment of judges, vote of no confidence, appointment of key state officials, veto and formation of government are analyzed in the article.
\end{abstract}

Keywords: checks, balances, system, democracy, Ukraine, Constitution, branches of state power.

The beginning of the process of political transformation in independent Ukraine, the consequences of which are still ongoing, has had a number of features. It is noteworthy that Ukraine's independence has set itself the dual task of moving to democratic forms of government The functioning of the system of checks and balances in Ukraine has also been significantly influenced by a number of objective factors, which has directly affected the peculiarities of its regulatory fixing and practical implementation.and creating a new legislative framework for the practical implementation of such a transition.

In addition, we may consider the significant ethnocultural transformations and the general deformation of the structure of the society, such phenomena as russification, changes the ethnic composition of the population of Ukraine. So we should also mention that there was the lack of democratic consciousness and culture.

The checks and balances system as an indicator of democratic was and remains a significant prerequisite for Ukraine's political progress. Therefore, the topic of the article is extremely relevant, because the study of the evolution of the practical application of elements of checks and balances remains a problematic and debatable scientific problem. Current political experience demonstrates the need for a theoretical justification for the development and historical practice of the system of checks and balances elements implementation in Ukraine.

Among researchers, who paid attention to the problem of studying the evolution of the system of checks and balances in Ukraine L. Sylenko, N. Haydaenko, N. Zhuk, V. Rabkalo and others should be mentioned. At the same time, notwithstanding the wide range of scholars who have paid attention to this aspect of the system of checks and balances, today there is no single integrated approach to the and history of the development of the checks and balances system elements in Ukrainian political experience.

Therefore, the aim of the article is to to investigate the peculiarities of the implementation of the elements of the system of checks and balances in the conditions of different Constitutions in Ukraine. To achieve this фшь, we will use such methods as: historical method (to show how historically the approach to the use of elements of the checks and balances system has changed), the method of document analysis (for a detailed analysis of the main normative legal acts of Ukraine), comparative method (to compare the main elements of the checks and balances system accorsing to different normative legal documents of Ukraine) the system method (to consider the elements of the checks and balances system as constituents systems) as well as methods such as induction, deduction, analysis and synthesis.

Taking into account the historical approach, the beginning of evolution in the checks and balances system in the independence of Ukraine in may be considered from two perspectives:

1) From the time, the practical use of the delimitation of the state powers and the functioning of the system of checks and balances was produced, without their improper legislative fixing.. Functioning of the checks and balances system between the branches of state power in Ukraine from 1991 to 1995 existed at the level of the norms of the Constitution of the Ukrainian Soviet Socialist Republic in 1978 and there should have been state legal bodies that regulated, invested in bowls when Ukraine was part of the USSR.

2) In accordance with the emergence of the first regulatory document in the history of independent Ukraine that would regulate relations between branches of state power (the de jure component). Therefore, the Constitutional Treaty of 1995, the Constitution of 1996 and the Law of Ukraine «On Amendments to the Constitution of Ukraine» of December 8, 2004 will be in the focus of our comparative analysis $[3 ; 6 ; 7]$.

For the first time in the history of independent Ukraine, the system of checks and balances acquired its legal formulation in the "Constitutional Treaty between the Verkhovna Rada of Ukraine and the President of Ukraine on the Fundamental Principles of Organization and Functioning of State Power and Local Self-Government in Ukraine for the until the New Constitution of Ukraine is adopted» of June 8, 1995. This document has become an important prerequisite for the adoption of the Constitution for an independent young democracy, as it outlined the basic principles of the distribution of branches of state power in order to overcome the economic, social and constitutional crisis for the first time in the history of independent Ukraine. The Constitutional Treaty stipulates that the absence of a basic law in the state $«$... prevents the proper functioning of the entire state mechanism both at the center and on the 
ground, hinders economic reforms» [6]. The Treaty also took into account the pronounced influence of the absence of the Constitution on the processes of democratization of society and the prospects of impoverishment of the vast majority of the population and social conflicts aggravation.

For the first time, the most extensive system of checks and balances was legally enshrined in the basic law of Ukraine - the Constitution, in 1996. The basic law of the state enshrined the presidential-parliamentary form of government with its inherent set of elements of the system of checks and balances. Subsequently, the system of checks and balances has been adjusted as a result of the introduction of Constitutional reform in 2004. Therefore, it is advisable to consider the evolution of changes in the main elements of the checks and balances system between branches of state power, given the regulatory approval of them in the relevant regulatory acts of Ukraine.

Impeachment.The Constitutional Treaty did not provide a possibility of bringing the President by the Verkhovna Rada of Ukraine to liability in the form of a special procedure impeachment. The lack of formal fixing of impeachment deprived Parliament of any real influence on the President and strengthened the position of the Head of State at all levels of government [6].

For the first time in the Constitution of 1996, according to Article 111 the President of Ukraine may be removed from office by the Verkhovna Rada of Ukraine in order of impeachment in case of committing treason or other crime [7].

On September 10, 2019, the Verkhovna Rada of Ukraine adopted the Law «On the Special Procedure for Removal of the President of Ukraine from office (impeachment)», which defines the legal and organizational bases for bringing the President of Ukraine to constitutional liability according to the impeachment procedure. The Law became the first legal act in the history of independent Ukraine that regulates the phased implementation of the impeachment procedure in Ukraine. The Law provides for participation in the impeachment procedure of the Constitutional Court of Ukraine, which monitors the constitutional procedure of investigation and consideration of the case, and the Supreme Court of Ukraine, which concludes whether the actions of the President contain treason or other crime [4].

Legislative initiative. According to the Treaty, the right of legislative initiative was exercised by the people's deputies of Ukraine, standing committees of the Verkhovna Rada of Ukraine, the President of Ukraine, the Cabinet of Ministers of Ukraine, the Supreme Court of Ukraine and the Supreme Arbitration Court of Ukraine. It is noteworthy that the Treaty provided for the right of the President to consider the bills introduced by him first and foremost, if this is necessary for the regulation of a certain sphere of public life. Such bills shall be submitted without delay to the plenary session by the Verkhovna Rada of Ukraine [6].

The right of legislative initiative in the Verkhovna Rada of Ukraine under the Constitution from 2004 belongs to the President of Ukraine, the People's Deputies of Ukraine and the Cabinet of Ministers of Ukraine [3]. The first Constitution also mention the National Bank of Ukraine among the holders of the legislative initiative. Bills designated as urgent by the President of Ukraine are subject to extraordinary consideration under both Constitutions [7].
Formation of courts and appointment of judges. The formation of courts of higher jurisdiction and the appointment of judges, in accordance with the Constitutional Treaty, are jointly conducted by the President and the Verkhovna Rada of Ukraine, but the President obviously has significant advantages in the formation of judicial bodies. Half of the judges of the Constitutional Court and its Chairman are appointed by the President upon formal approval of the Verkhovna Rada. In addition, the President has the power to appoint the President of the Supreme Court of Ukraine and the President of the Supreme Arbitration Court of Ukraine. Appointment by the Verkhovna Rada of Ukraine is also subject to consideration by the President of the composition of the Supreme and Supreme Arbitration Tribunals of Ukraine. At the request of the Ministry of Justice of Ukraine, on the basis of an agreement with the Supreme Court of Ukraine and the Supreme Arbitration Court of Ukraine, the President also appoints judges of general and arbitration courts [6].

Under the 1996 Constitution, the President, the Verkhovna Rada, and the Congress of Judges of Ukraine jointly form the composition of the Constitutional Court of Ukraine. At the same time, Article 106, paragraph 23 provides that the President shall form courts in the manner prescribed by law [7]. However, in the modern model of the Constitution, this paragraph was deleted in connection with the adoption of the Law of Ukraine «On Amendments to the Constitution of Ukraine (on Justice)» of June 02, 2016, according to which most of the powers in the field of appointing judges and forming courts to a specialized independent body, the High Council of Justice. In our view, the adoption of this law has made the process of appointing judges more transparent and independent.

Vote of no confidence.This element of the system of checks and balances under the Constitutional Treaty constituted the right of the Verkhovna Rada to declare no confidence to the all personnel of the Government, or to individual members. The exercise of this right entails their resignation. The Treaty outlines certain cases where the Verkhovna Rada of Ukraine is entitled to express a vote of no confidence in the Cabinet of Ministers. Article 22 enshrines the possibility of expressing a vote of no confidence in case of disagreement with the submitted Program of work of the newly created Government of Ukraine. In case of approval of the Program of the Government, the Verkhovna Rada of Ukraine is entitled to express a vote of no confidence not earlier than after one year of its work. Article 33 of the Constitutional Treaty provides the Verkhovna Rada to express a vote of no confidence in the Government as a whole, or individual members thereof, in case of late submission of the draft State Budget of Ukraine [6].

Under both versions of the Constitutions, the Verkhovna Rada of Ukraine exercises control over the Cabinet of Ministers of Ukraine and has the right to adopt a resolution of no confidence in the Cabinet of Ministers of Ukraine by a majority of the constitutional composition of the Verkhovna Rada of Ukraine. The Constitution provides the possibility of expressing distrust not more than once during one regular session, as well as during the year following the adoption of the Program of Activities of the Cabinet of Ministers of Ukraine [3; 7]. 
Appointment of key public officials. Due to the Constitutional Treaty of 1995, the President of Ukraine submits to the Verkhovna Rada of Ukraine proposals for the composition of the Central Election Commission. The President heads the National Security Council and approves other personnel. In addition, the President of Ukraine nominates the Prosecutor General of Ukraine, the Chairman of the Board of the National Bank of Ukraine, and the Verkhovna Rada, in turn, formally appoints these key officials. The President also establishes the right to appoint and recall diplomatic representatives of Ukraine in foreign countries and international organizations, accepts the credentials and certificates of diplomacy of foreign diplomats accredited by him. In fact, the President retained the power to influence the sole appointment of key public officials [6].

Under the Constitution of 1996, the President appoints and dismisses with the consent of the Verkhovna Rada of Ukraine the Chairman of the Antimonopoly Committee of Ukraine, the Chairman of the State Property Fund of Ukraine, the Chairman of the State Committee for Television and Radio Broadcasting of Ukraine. In addition, the Head of State appoints and dismisses the Prosecutor General of Ukraine with the consent of the Verkhovna Rada of Ukraine. The President, together with the Verkhovna Rada of Ukraine, appoints and dismisses half of the Board of the National Bank of Ukraine and the National Television and Radio Broadcasting Council. At the request of the President, the Verkhovna Rada of Ukraine appoints and dismisses the Chairman of the National Bank of Ukraine and members of the Central Election Commission [7]. These provisions on the appointment of key state bodies and individual officials have not undergone significant changes under the Law of Ukraine «On Amendments to the Constitution of Ukraine» of December 08, 2004. It is worth noting that the Constitution model of 2004 added a subparagraph to Article 85 , paragraph 12 , which refers to the appointment of the Chairman of the Security Service of Ukraine by the Verkhovna Rada of Ukraine upon the submission of the President [3].

At the same time, with regard to the appointment of the Chairman of the Antimonopoly Committee of Ukraine, the Chairman of the State Property Fund of Ukraine, the Chairman of the State Committee for Television and Radio Broadcasting of Ukraine - they, under the Constitution of 1996, only require the Verkhovna Rada's consent to their appointment, and under the Constitution of 2004 their appointment depends on the Verkhovna Rada of Ukraine greater including the formal submission of the President.

Both versions of the Constitution provide for the Verkhovna Rada's consent to the appointment of the Prosecutor General of Ukraine by the President, and enshrines the President's right to confer higher military and diplomatic ranks. In addition, the President has a fixed right to appoint and dismiss senior commanders of the Armed Forces of Ukraine and other military formations, taking into account his status as Commander-in-Chief of the Armed Forces of Ukraine and Chairman of the National Security and Defense Council of Ukraine.

Veto. According to the Constitutional Treaty, the President promulgates with his signature the laws of Ukraine adopted by the Verkhovna Rada of Ukraine. In case of disagreement with the content of the law, the President is entitled within two weeks to veto the law and send it for reconsideration with his remarks. However, the Treaty does not set out procedures for overcoming the presidential veto. However, there is an obligation to reconsider a law that has been subject to a presidential veto. At the same time, the Treaty provides for the right of the Verkhovna Rada of Ukraine to veto the decrees of the President of Ukraine in case of inconsistency of their Constitution and laws of Ukraine with simultaneous appeal to the Constitutional Court of Ukraine [6].

The veto right enshrined in the Constitution of 1996 and the Constitution of 2004 excludes the possibility to veto laws relating to the amendment of the Constitution $[3 ; 7]$.

Formation of government. According to the Constitutional Treaty, the President is the head of the executive branch of power in Ukraine. Within one month after taking his office, or from the date of resignation of the previous composition of the Government, he appoints the Prime Minister of Ukraine and forms the composition of the Government of Ukraine - the Cabinet of Ministers of Ukraine. In addition, the President creates, reorganizes and liquidates ministries, departments and other central and local bodies of state executive power branch within the limits of the state budget of Ukraine, and appoints and dismisses the heads of these bodies. Also, the President has the power to repeal acts of central and local bodies of state executive power in case of their inconsistency with the Constitution, the laws of Ukraine, as well as decrees and orders of the President of Ukraine [6].

The Constitution of 1996 provides the procedure pf appointment of the Prime Minister of Ukraine with the consent of the Verkhovna Rada of Ukraine; termination of his powers and decision on his resignation. On the proposal of the Prime Minister of Ukraine, the President appoints members of the Cabinet of Ministers of Ukraine, heads of other central executive bodies, as well as heads of local state administrations and suspends their powers in these positions. In this way, the President creates, reorganizes and liquidates ministries and other central executive bodies [7]. At the same time, according to the Constitutional Reform of 2004 the President proposes to the Verkhovna Rada of Ukraine on the proposal of the coalition of deputies of the Verkhovna Rada of Ukraine. The President should submit a proposal for consideration of the Prime Minister's candidature no later than the fifteenth day after receiving such proposal and submits it to the Verkhovna Rada. Also the President makes a submission of the Minister of Defense of Ukraine, the Minister for Foreign Affairs of Ukraine and other members of the Cabinet of Ministers of Ukraine [3].

Under the Constitution of 1996, the President may, at his own discretion, repeal acts of the Cabinet of Ministers of Ukraine, while under the Law of Ukraine «On Amendments to the Constitution of Ukraine» of 2004 he may suspend their acts on grounds of non-compliance with the Constitution, while simultaneously appealing to the Constitutional Court Of Ukraine.

The Cabinet of Ministers of Ukraine is accountable and exercises its authority before the President of Ukraine under the Constitution of 1996, while at the same time, under the Constitution of 2004, he is accountable to the President and the Verkhovna Rada of Ukraine and is under the control and accountability of the Verkhovna Rada of Ukraine. It should be added that the Cabinet of Ministers of Ukraine in its work 
is guided by the Constitution, laws of Ukraine and acts of the President of Ukraine, in accordance with the Constitution of 1996 [7]. At the same time, the Constitution of 2004 does not stipulate powers by the acts of the Head of State [3].

An important difference between the Constitutions of 1996 and 2004 is the envisaged fulfillment of the President's duties in the event of early termination of his/her powers: these powers are transferred to the Prime Minister of Ukraine (acoording to the Constitution of 1996);-- they are performed by the Chairman of The Verkhovna Rada of Ukraine (according to the constitutional reform of 2004) [3; 7].

Dissolution of Parliament. The Constitutional Treaty does not provide the possibility of the President to dissolve the Parliament [6].

Under the Constitution of 1996, the President of Ukraine may terminate the powers of the Verkhovna Rada of Ukraine ahead of time if plenary sessions cannot begin within thirty days of one regular session. The version of the Constitution of 2004 added two more grounds for dissolving the Parliament by the President: if a coalition of parliamentary factions has not been formed in the Verkhovna Rada of Ukraine within one month; if within sixty days after the resignation of the Cabinet of Ministers of Ukraine the personal composition of the Cabinet of Ministers of Ukraine has not been formed [7].

From the above analyzed elements of the checks and balances system, it is clear that in fact the Constitutional Treaty of 1995 enshrined the presidential form of government in Ukraine. This form of government was evidenced by the fact that the President concentrated in his hands the entirety of the executive power. In addition, the procedures for the formation of a court of higher jurisdiction, a body of constitutional oversight, as well as judges of general and arbitral tribunals testify to the factual control of the judicial branch of power by the head of state. It is also worth noting that ministers, heads of other central bodies of state power, heads of bodies of state executive power of oblasts are accountable before the President of Ukraine. At the same time, Parliament's only counterbalance against the President was to use a vote of no confidence in the government; however, the Treaty does not clearly regulate all possible instances of this element of checks and balances system.

The system of checks and balances under the Constitutional Treaty was characterized by an imbalance between the legislative and executive branches of government, with greater influence of the latter. The President's powers extend not only to the executive branch, which is accountable to him and under his control, but the head of state also has a wide range of powers over the judicial branch. In fact, the judicial branch is formed under the influence and will of the President, and the legislative branch reserves the right to formally appoint them to office [6].

The Constitution of 1996 enshrined the presidentialparliamentary form of government in Ukraine. The President has concentrated in his hands much of the powers pertaining to the functioning of the executive branch of power. To a greater extent, the Prime Minister of Ukraine and the Cabinet of Ministers of Ukraine are under the control and accountability to the President of Ukraine, and the latter has a greater influence on the appointment of the Prime Minister and Government personnel. In addition, the President has a wide range of staffing responsibilities. Unlike the Constitution of 2004, the President has the advantage of appointing key government officials than the Verkhovna Rada of Ukraine.

Today, Ukraine is a parliamentary-presidential republic with an inherent set of elements of a system of checks and balances. The amendments to the Constitution, which were introduced in 2004, are now considered to be valid (according to the restoration of these amendments in 2014) [3] and, therefore, all the features of this year's constitution model have been taken into account when implementing the mechanisms of checks and balances between branches of state power. The return to the Constitution model of 2004 took place on the backdrop of the tragic events surrounding the Dignity revolution in Ukraine. Acoording to the Law, the part of the powers of the President in the influence on the executive branch again transferred to the Verkhovna Rada.

To conclude, we shoud mention that the the system of checks and balances is an important attribute of a democratic political regime. In Ukraine, the process of formation and practical implementation of the system of checks and balances has gone its way. Regulatory consolidation of such key elements of the system of checks and balances has passed several stages of development. Ukraine has tried the following forms of government: from presidential to parliamentary-presidential. At present, our country faces a number of important tasks to improve the functioning of the existing elements of the system of checks and balances by the type of parliamentary-presidential republic. There are many problems in the practical application of the elements of the checks and balances system in Ukraine. Therefore, the theoretical study of the elements of the system of checks and balances is important for further scientific research.

\section{ЛИТЕРАТУРА}

1. Гайдаєнко Н. В. Проблеми наукового дослідження системи стримувань i противаг в сучасній політичній теоpiï/Н.В.Гайдаєнко // Сучасна українська політика. Політики і політологи про неї. - К., 2005. - Вип. 7. - С. 152-158

2. Жук Н. А. Система стримувань і противаг у державному апараті: витоки та основний зміст/Н. А. Жук // Вісник Академії правових наук України. - 2003. - № 4 (35). - С. 52-62

3. Закон «Про внесення змін до Конституції України» від 8.12.2004 p., No 222-IV [Електронний ресурс] // Офіційний веб-портал Верховної Ради України. Законодавство України. Режим доступу: https://www.zakon.rada.gov.ua/ laws/main/2222-15

4. Закон «Про особливу процедуру усунення Президента України $з$ поста (імпічмент)» від 10.09.2019 р., No 39-IX [Електронний ресурс] // Офіційний веб-портал Верховної Ради Ук-

раїни. Законодавство України. - Режим доступу: https://www.zakon.rada.gov.ua/laws/main/39-20

5. Закон України «Про відновлення дії окремих положень Конституції України» від 21.02.2014 p., № 742-VII [Електронний ресурс] // Офіційний веб-портал Верховної Ради України. Законодавство України. - Режим доступу: https://www.zakon.rada.gov.ua/laws/show/742-18

6. Конституційний договір між Верховною Радою України та Президентом України про основні засади організації та функціонування державної влади і місцевого самоврядування в Україні на період до прийняття нової Конституції України від 8.06.1995 р. [Електронний ресурс] // Офіційний вебпортал Верховної Ради України. Законодавство України. Режим

доступу: 
https://www.zakon.rada.gov.ua/laws/show/1\%D0\%BA/95$\% \mathrm{D} 0 \% \mathrm{~B} 2 \% \mathrm{D} 1 \% 80$

7. Конституція України від 28.06.1996 року [Електронний ресурс] // Офіційний веб-портал Верховної Ради України. Законодавство України. - Режим доступу:
https://www.zakon.rada.gov.ua/laws/main/254\%D0\%BA/96\%D $0 \% \mathrm{~B} 2 \% \mathrm{D} 1 \% 80$

8. Силенко Л. М. Система «стримань і противаг» та закріплення iї складових в Конституції України/Л. М. Силенко // Науковий вісник Національної академії внутрішніх справ України. - 1998. - № 3. - C. 37-39

\section{REFERENCES}

1. Haidaenko N.V. Problems of scientific Research of the System of Checks and Balances in contemporary Political Theory/N.V. Haidaenko // Contemporary Ukrainian Politics. Politicians and political scientists about it. - K., 2005. - Vol. 7., P. 152158.

2. Zhuk N. A. System of Checks and Balances in the State Apparatus: Origins and main Content/N. A Zhuk // Bulletin of the Academy of Legal Sciences of Ukraine. - 2003. - № 4 (35). - P. $52-62$

3. The Law of Ukraine «On Amendments to the Constitution of Ukraine» from 8 Dec. 2004 No 222-IV [Digital resource] // The official web-portal of the Verkhovna Rada of Ukraine. The Legislation of Ukraine. -Access mode: https://www.zakon.rada.gov.ua/laws/main/2222-15

4. The Law of Ukraine «On the special Procedure for the removal of the President of Ukraine from Office (Impeachment)» from 10 Sept. 2019, No 39-IX [Digital resource] // The official web-portal of the Verkhovna Rada of Ukraine. The Legislation of Ukraine. Access mode: https://www.zakon.rada.gov.ua/laws/show/3920/sp:info-
5. The Law of Ukraine «On the renewal of certain provisions of the Constitution of Ukraine» from 21 Febr. 2014, № 742-VII [Digital resource] // The official web-portal of the Verkhovna Rada of Ukraine. The Legislation of Ukraine. - Access mode: https://www.zakon.rada.gov.ua/laws/show/742-18

6. Constitutional Treaty between the Verkhovna Rada of Ukraine and the President of Ukraine on the Fundamental Principles for the Organization and Functioning of State Power and Local SelfGovernment in Ukraine until the New Constitution of Ukraine is adopted from 8 June 1995[Digital resource]. - Access mode: https://www.zakon.rada.gov.ua/laws/show/ru/1\%D0\%BA/95\%D0\%B2\%D1\%80/ed199506 08

7. Constitution of Ukraine from 28 June 1996 [Digital resource] // The official web-portal of the Verkhovna Rada of Ukraine. The Legislation of Ukraine. - Access mode: https://www.zakon.rada.gov.ua/rada/show $\quad$ 254\%D0\%BA/96$\% \mathrm{D} 0 \% \mathrm{~B} 2 \% \mathrm{D} 1 \% 80$

8. Sylenko L.M The System of Checks and Balances and the fixing of its Components in the Constitution of Ukraine/L. M. Sylenko // Scientific Bulletin of the National Academy of Internal Affairs of Ukraine. - 1998. - № 3. - P. 37-39. 